
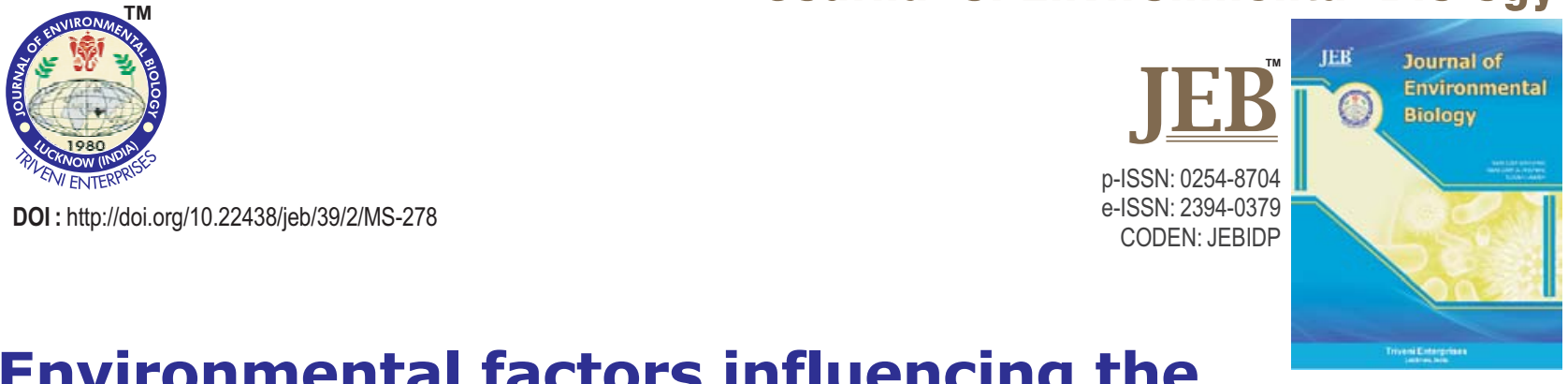

\title{
Environmental factors influencing the population of whitefly and leaf curl disease incidence in chilli
}

\section{Authors Info}

\section{A.N. Chaubey and R.S. Mishra* Department of Plant Pathology, Narendra Dev University of Agriculture and Technology, Faizabad-224 229, India}

*Corresponding Author Email : drramsumanmishra@gmail.com

Key words

Capsicum annum Leaf curl disease Whitefly

\section{Publication Info}

Paper received : 24.02 .2016 Revised received : 19.07.2016 Re-revised received : 20.04.2017 Accepted : 27.06.2017

\begin{abstract}
\end{abstract}
Aim : Chilli (Capsicum annum) is an important spice crop cultivated all over the world. The importance of chilli leaf curl disease has been recognized for many years because it is one of the most devastating disease in chilli growing area and transmited through the vector whitefly (Bemisia tabaci Genn) under favorable environmental conditions. The present study was conducted to study the effect of meteorological factors on whitefly population and incidence of chilli leaf curl virus disease.

Methodology : A rectangular cage was formed by ply wood and fiber glass. The ply wood plate was cut according to required size and made in rectangular form. Randomly selected five plants of each plot in rectangular cage were observed population of white fly and disease intensity of leaf curl virus at weekly interval starting from 20 days after transplanting at the morning hours (6-7 a.m.) on the defined day. Meteorological data viz., maximum temperature, minimum temperature, relative humidity, total rain fall and wind velocity were obtained from the meteorological observatory, Narendra Dev University of Agriculture and Technology, Faizabad.

Results : The first appearance of white fly was recorded on $10^{\text {th }}$ standard week and rapid progress of white fly population was recorded from $11^{\text {th }}$ standard week to $17^{\text {th }}$ standard weeks in 2014 and $18^{\text {th }}$ week in 2015 . The increase in white fly population was positively correlated with minimum and maximum temperature. Disease incidence of chilli leaf curl virus was significant and positively correlated with white fly population ( $r=0.93$ in 2014 and $r=0.89$ in 2015). The maximum percent leaf curl increase was observed on $19^{\text {th }}$ standard week when white fly population was highest in the field.

Interpretation: The increase or decrease of leaf curl virus disease of chilli was directly correlated with vector population and vector population was
Chilli leaf curl disease, one of the most devastating disease in chilli, is transmit through whitefly (Bemisia tabaci Genn) under favorable environmental conditions

$\downarrow$

Randomly selected five plants from each plot in rectangular cage were observed population of white fly and disease intensity of leaf curl virus at weekly interval

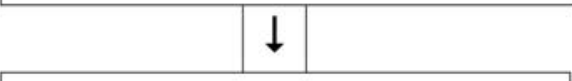

Meteorological data viz., maximum temperature, minimum temperature, relative humidity, total rain fall and wind velocity were obtained from the meteorological observatory
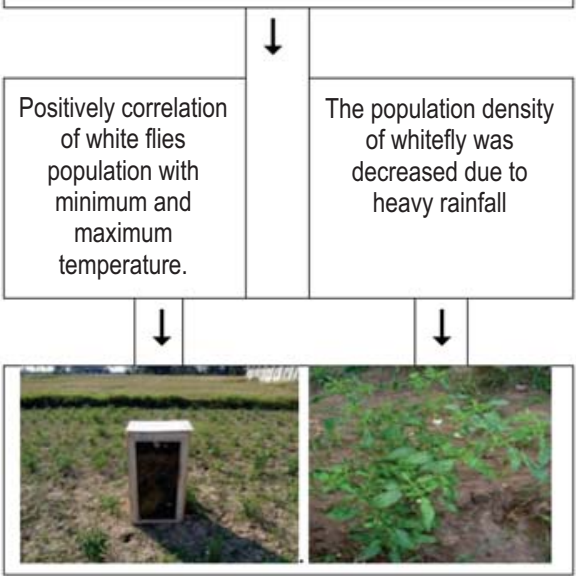
concluded that whitefly population and leaf curl incidence increased with increasing the temperature, as well as relative humidity and decreased with the occurrence of rainfall. 


\section{Introduction}

Chilli, an important crop of India is used as green and dry powder for enhancing the taste of vegetable, pulses, pickles etc. The crop was grown in 792.1 thousands hectares of area and 1260 thousands tonnes of dry chilli was produced in Uttar Pradesh during 2012-13 (Anonymous, 2013). The crops are affected by several disease causing pathogens like fungi, bacteria and viruses. Leaf curl virus disease is most destructive one i.e., transmitted with whitefly. It was first observed in India by Vasudeva (1954). Now the disease occurs at all stages of plant growth. If the disease appears at an early stage of plant growth, the yield loss has been reported upto $80-90 \%$ (Singh et al., 1979). Meena et al. (2006) observed maximum incidence of leaf curl viruses ranged from 25-50\% in winter at Shaphara of Rajasthan. The severity of disease is greatly influenced by a number of factors such as meteorological parameters, vector population, cropping seasons and varietal susceptibility. Singh et al. (1989) reported that leaf curl viral disease is spread more during summer due to favorable temperature for buildup of both vector population and incidence of disease.

Gupta et al. (2010) reported that whitefly efficiently transmits leaf curl virus from infected cotton plant to healthy cotton plant. Whitefly acts as a sole vector for more than hundred plant viruses to cause disease on many commercial crops in different parts of world (Jones, 2003). The severity of disease depends on population of whitefly (Bemasia tabaci) that can rapidly disseminate viruses in field even when population is not appreciable, and cause severe crop damage in susceptible plantings. The population dynamics of whitefly varies during different seasons of the year because it is greatly influenced by atmospheric humidity, temperature and total rainfall (Horowitz et al., 1984). Borah and Bordoloi (1998) observed a positive significant correlation between disease incidence and whitefly population with temperature and rainfall.

In view of the above, the aim of the present investigation was to know the factors influencing development of whiteflies in chillies and its influence on leaf curl disease severity. Therefore in the present study, the effect of meterological factors on the population dynamic of white fly and development leaf curl virus in chilli was studied.

\section{Materials and Methods}

Counting of white fly (Bemisia tabaci) and incidence of chilli leaf curl : The studies on population dynamics of white fly were conducted during 2014 and 2015 (February to May) at Student's Instructional Farm of Narendra Deva University of Agriculture and Technology, Kumarganj, Faizabad, India. The geographical coordinates of experimental sites are $26.470 \mathrm{~N}$ latitude, $82.120 \mathrm{E}$ longtitude and $113 \mathrm{~m}$ above sea level in the north Indo-Gangetic plain. Faizabad comes under sub-tropical zone and is often subjected to extreme weather, i.e., hot summers and cold winters. Susceptible plant variety Faizabadi Kala were transplanted in
$2.25 \times 1.80 \mathrm{~m}$ plot size and was maintained plant to plant and row to row distance $60 \times 20 \mathrm{~cm}$. The whitefly populations were taken in terms of number of whitefly per plant using rectangular cage 45 $\mathrm{cm}$ long $30 \mathrm{~cm}$ wide and $90 \mathrm{~cm}$ high, according to the stage of the crop. The rectangular cage was formed by ply wood and fiber glass. The ply wood plate was cut according to required size and made in rectangular form. The inner side of cage was painted black for inducing darkness inside the cage and covered it with transparent fiber glass. However, bottom of rectangular cage remained open. The cage was placed on plant for recording the white fly population. The flies congregated on the inner surface of glass screen due to their phototactic behavior, which were counted easily. Randomly selected five plants of each plot were observed for the population of white fly at weekly interval starting from 20 days after transplantation. The observations were recorded during morning hours (6-7 a.m.) on the defined day. Meteorological data viz., maximum temperature, minimum temperature, relative humidity, total rain fall and wind velocity were obtained from the meteorological observatory, Narendra Dev University of Agriculture and Technology, Faizabad. The correlation coefficient was worked out with different meteorological parameters and whitefly population collected in rectangular cage. Multiple regressions was also analyzed taking meteorological factors as an independent variable for determining the combined effects of all these factors on the buildup of whitefly population (Draper and Smith, 1981). Percent incidence of chilli leaf curl disease was calculated by the following formula:

$$
\text { Disease incidence }(\%)=\frac{\begin{array}{c}
\text { Number of infected } \\
\text { plants per plots }
\end{array}}{\text { Number of plants }} \times 100
$$

The diseased plant of chilli leaf curl was identified on the basis of symptoms. The weekly observations were taken as percent of infected plants and total number of adult whitefly on five plants/plots. Statistical analysis of percent disease incidence data was carried out. The correlation coefficient was calculated by the method suggested by Verma et al. (1989).

\section{Results and Discussion}

Chilli leaf curl disease is known for last the 56 years; however, information on the disease incidence and its transmission through whitefly (Bemasia tabaci) is meagre. The most notable field symptoms of leaf curl disease is curling, puckering, presence of numerous small and curly leaves on the upper portion of plants that gives a bushy appearance of the affected plants that produced few or no fruits. The epidemic of chilli leaf curl virus depend on whitefly (Bemasia tabaci) population, which induces severe leaf curl symptoms in chilli and becomes a viruliferous vector (Senanayake etal., 2012; Cohen etal., 1992).

Whitefly population was observed within the selected cultivar of chilli along with disease from $8^{\text {th }}$ to $20^{\text {th }}$ standard week 
Table1 : Weekly incidence of white fly (Bemisia tabaci) and leaf curl virus disease of chilli during 2014-2015

\begin{tabular}{|c|c|c|c|c|c|c|}
\hline $\begin{array}{l}\text { Standard } \\
\text { weeks }\end{array}$ & $\begin{array}{l}\text { Average no. of } \\
\text { whitefly/five plant }\end{array}$ & $\begin{array}{l}\text { Disease } \\
\text { incidence (\%) }\end{array}$ & $\begin{array}{l}\text { Disease } \\
\text { increase (\%) }\end{array}$ & $\begin{array}{l}\text { Average no. of } \\
\text { whitefly/five plant }\end{array}$ & $\begin{array}{l}\text { Disease } \\
\text { incidence (\%) }\end{array}$ & $\begin{array}{l}\text { Disease } \\
\text { increase (\%) }\end{array}$ \\
\hline$\overline{8}$ & 0 & 0 & 0 & 0 & 0 & 0 \\
\hline 9 & 0 & 0 & 0 & 0 & 0 & 0 \\
\hline 10 & 2.15 & 0 & 0 & 2.95 & 0 & 0 \\
\hline 11 & 2.32 & 3.56 & 3.56 & 7.56 & 4.2 & 4.2 \\
\hline 12 & 5.76 & 11.33 & 7.77 & 8.11 & 8.46 & 4.26 \\
\hline 13 & 4.21 & 14.46 & 3.13 & 8.76 & 15.23 & 6.77 \\
\hline 14 & 7.56 & 21.36 & 6.9 & 11.56 & 21.33 & 6.1 \\
\hline 15 & 6.23 & 25.13 & 4 & 13.26 & 33.46 & 12.13 \\
\hline 16 & 9.56 & 37.23 & 12.1 & 14.34 & 34.77 & 1.31 \\
\hline 17 & 8.21 & 44.21 & 6.98 & 13.21 & 36.45 & 1.68 \\
\hline 18 & 7.23 & 51.46 & 7.25 & 18.23 & 49.96 & 13.51 \\
\hline 19 & 11.46 & 64.64 & 13.18 & 21.3 & 77.85 & 27.89 \\
\hline 20 & 15.32 & 81.36 & 16.72 & 17.26 & 84.64 & 6.79 \\
\hline Correlation & & 0.937827 & & Correlation & & 0.890292 \\
\hline
\end{tabular}

for consecutively two years and the results are presented in Table 1. The whitefly population was first observed on $10^{\text {th }}$ week and disease incidence was recorded on $11^{\text {th }}$ week during both the year 2014 and 2015. The disease incidence was gradually increased with the increase of whitefly population. Variation in whitefly population and disease incidence among the meteorological week were observed in both the years. The highest whitefly population was recorded on $20^{\text {th }}$ standard week in 2014 (15.32) and 19 th standard week in 2015 (21.3). Senanayake et al. (2012) reported that the virus was transmitted even by single whitefly, infecting $66.6 \%$ of the inoculated chilli plants and eight whitefly per plant resulted in $100 \%$ transmission of chilli leaf curl virus. The leaf curl disease was first observed in $11^{\text {th }}$ week and raised in $12^{\text {th }}$ week, then percent increase reduced abruptly on $13^{\text {th }}$ week and again increase was found on $14^{\text {th }}$ week and slightly decreased by $15^{\text {th }}$ week (6.9 to 4.0$)$ which again suddenly increased from 4.0 to $12.1 \%$ on $16^{\text {th }}$ week and 13.18 to $16.72 \%$ on $20^{\text {th }}$ week of 2014 . In 2015, a gradual percent disease increase was observed till $15^{\text {th }}$ week, whereas increase rate was low on $16^{\text {th }}(1.31 \%)$ and $17^{\text {th }}$ week $(1.68 \%)$. It again increased @ $13.51 \%$ on $18^{\text {th }}$ week and $27.89 \%$ on $19^{\text {th }}$ week of 2015 .

The result of the experiment on population dynamic of whitefly revealed that the population of whitefly gradually increased with increase of temperature and humidity, and declined with rainfall during both the consecutive years (2014 and 2015). Data of whitefly population, maximum and minimum temperature, relative humidity, total rainfall and wind velocity of average weekly are presented in Table 2 . The whitefly (Bemasia tabaci) appeared on third week of March $\left(10^{\text {th }}\right.$ meteorological week) and continued upto first week of June $\left(20^{\text {th }}\right.$ metrological week) during 2014 and 2015. The population density of whitefly was affected by total rainfall during the week when heavy rainfall $(4.2 \mathrm{~mm})$ occurred on $11^{\text {th }}$ week, $9.6 \mathrm{~mm}$ on $15^{\text {th }}$ week, $37 \mathrm{~mm}$ on $17^{\text {th }}$ week and $52.6 \mathrm{~mm}$ on $18^{\text {th }}$ week respectively. The whitefly population was recorded $2.32,6.23,8.21$ and 7.23 per plant during 2014 at each metrological week, respectively. In 2015, whitefly population gradually increased at all meteorological week except $16^{\text {th }}$ meteorological week when the increase in density was less (1.08) due to occurrence of low rainfall $(17 \mathrm{~mm})$ during that week. Similar finding were reported by Latif and Akhter (2013) and Atwal Dhaliwall (2007) who reported that heavy rainfall reduced population of whitefly. During rain whitefly eggs and nymphs were reduced (Castle, 2001). The correlation studies were positively significant with the whitefly population $(r=0.96488)$ in 2014 and $(r=0.91050)$ 2015. The relation with percent disease intensity of chilli leaf curl was also found positive with significant correlation during both the consecutive year. Statistical analysis showed a positive significant correlation between minimum temperature and whitefly population $(r=0.8758)$ in 2014 and $(0.8927)$ in 2015. The maximum numbers of whitefly were observed between $150 \mathrm{C}$ to $25.6^{\circ} \mathrm{C}$ where minimum temperature was recorded above or below the limit and the vector populations were found less. After statistical analysis with whitefly population and total rainfall was found negative with in significant correlation during both the years. Hence, whitefly population drastically decreased when heavy rainfall occurred during that week. Percent disease intensity was also observed to the negative with insignificant correlation with rainfall in 2014 and significant in 2015 ( $r=0.54905)$. Relative humidity was observed negative with significant correlation for whitefly population i.e., $r=0.87836$ and $r=0.88291$ in 2014 and 2015, respectively. The correlation with percent disease intensity in 2014 was $r=-0.76137$ and $2015 r=-0.94997$. The maximum whitefly population was recorded between 43.1 to $65.5 \%$ average relative humidity. 


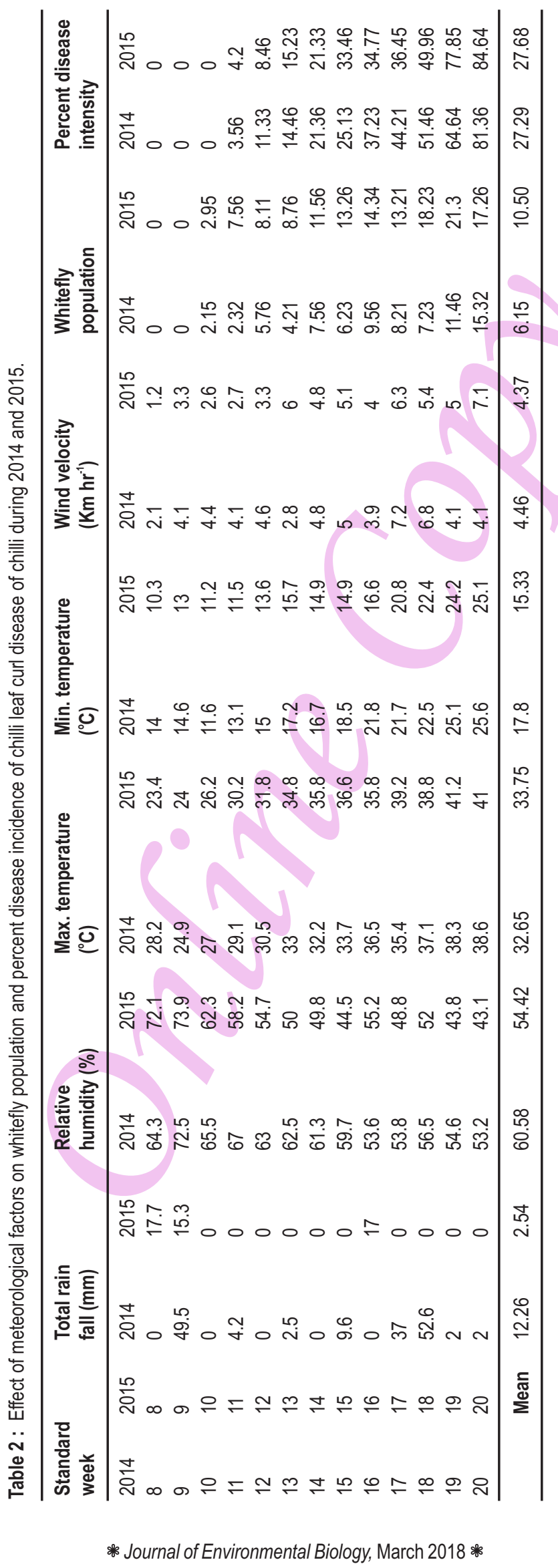


Statistical analysis data showed positive in significant correlation with white fly and percent disease incidence (PDI) in 2015, but positive and significance correlation was found in 2014 for whitefly ( $r=0.743059)$ and PDI ( $r=0.748239)$. The multiple regression equation of vector population and PDI due to meteorological factors are expressed by corresponding regression coefficient along with $R, R^{2}$, adjusted $R^{2}$ and standard error estimates. It was observed that rainfall, relative humidity, minimum temperature, maximum temperature and wind velocity were collectively responsible for the buildup of vector population in the field. Significant positive correlations were found within vector population, per cent disease incidence and different meteorological factors from the adjusted values. The past data revealed that meteorological factors were responsible up to $96 \%$ in 2014 and $92 \%$ in 2015 , for buildup of white fly population by direct count method (rectangular cage). The total rainfall showed significant correlation with buildup of white fly population during both the years. Thus, the minimum and maximum temperature, relative humidity and wind velocity were observed predictor variables for the increase and decrease of white fly population, which is a major disseminator's factor of disease. The increase or decrease of leaf curl virus disease of chilli was directly related with the vector population (De et al., 2005) and the whitefly population was clearly determined by environmental factors (Zeshan et al., 2015). It is concluded that whitefly population and leaf curl incidence increased with increasing the temperature as well as relative humidity and decreased with the occurrence of rainfall. The present study showed that whitefly and leaf curl disease incidence occurred highest during April and May in comparison to June and July. Hence, the study is useful for planning to control leaf curl disease by timely and judicious use of insecticide.

\section{Acknowledgment}

The authors are grateful to the office of "Vice- chancellor" for their moral support during the research work.

\section{References}

Anonymous: Area and production of vegetable crops, 2012-13. National Horticulture Board, p. 29 (2013).

Atwal, A.S. and G.S. Dhaliwall: Agricultural pests of south Asia and their management. Kalayani Publishers, New Delhi, India, p. 505 (2007).

Borah, R. K. and D. K. Bordoloi : Influence of planting time on the incidence of leaf curl virus disease and whitefly population on tomato. Indian J. Virol., 14, 71-73 (1998).

Castle, S. J: Differences between cotton and melon in host acceptance by Bemisia tabaci, Proceedings of the belt wide cotton conference. National Cotton Council, Memphis, TN, pp. 1056-1059 (2001).
Cohen, S., J. Kern, I. Harpaz and J. R. Ben : Epidemiology studies of the tomato leaf curl virus (TYLCV) in Jordan Valley, Israel. Phytoparasitica, 16, 259-270 (1992).

De, B. K., A. K. Saha and P.S. Nath: Influence of meterological factor on the buildup of white fly (Bemasia tabaci) vector population and incidence of chilli leaf curl virus disease in the plains of west Bengal. J. Mycopathol. Res., 43, 195-201(2005).

Draper, N. R. and H. Smith: Applied Regression Analysis. $3^{\text {rd }}$ Edn., New York, Wiley (1981).

Gupta, V. K., R. Sharma, S. Singh, J. Jindal and V. K. Dilawari : Efficiency of Bemisia tabaci (Gennadius) populations from different plant host for acquisition and transmission of cotton leaf curl virus. Indian J. Biotech., 9, 271-275(2010).

Horowitz, A. R. : Population dynamics of Bemisia tabaci (Gennadius) with special emphasis on cotton field. Agricult. Ecosys. Environ., 17, 37-47(1986).

Horowitz, A.R., H. Podoler and D. Gerling: Analysis of the tobacco whitefly Bemisia tabaci (Gennadius) in cotton fields in Israel. Acta Oecolo. Oecologia Appli., 5, 221-233 (1984).

Jones, D.R.: Plant viruses transmitted by whiteflies. Eur. J.Plant Pathol., 109, 195-219 (2003).

Latif, M. A. and N. Akhter: Population dynamics of whitefly on cultivated crops and its management. Int. J. Biores. Stress Manag., 4, 576581(2013).

Meena, R., V. Panti and D. K. Arora : An epidemic of chilli leaf curls disease in Rajasthan. J. Phytol. Res., 19, 335-336 (2006).

Singh, S., B. R. Gupta, S. P. Pande and D. P. Tripathi: Response of some chilli lines to mosaic and leaf curl diseases. Indian J. Virol., 6, 113115(1990).

Senanayake, D. M. J. B., A. Verma and B. Mandal : Virus-vector relationship, host range, detection and sequence comparison of chilli leaf curl associated with an epidemic of leaf curl disease of chilli in Jodhpur, India. J. Phytopathol., 160, 146-155(2012).

Singh, S. J., K. S. Sastry and K. S. M. Sastry: Combating leaf curl virus in chilli. Ind. Hort., 24, 9-10(1979).

Singh, S. J., K. S. Sastry and K. S. M. Sastry: Efficacy of different insecticides and oil in the control of leaf curl virus in chilli. Zeit. Pflanzens., 86, 253-256 (1979).

Sinha, B. and J. Trafdar : Epidemiological study of SPVD transmission in WestBengal. Bioscan, 9, 1237-1242 (2014).

Stansly, P. A., D. J. Schuster and T. X. Liu : Apparent parasitism of Bemisia argetifolii (Homoptera : Aleyrodidae) by Aphelinidae (Hymenoptera) on vegetable crops and associated weeds in South Florida. Biological Control, 9, 49-57 (1997).

Vasudeva, R. S.: Report of the division of mycology and plant pathology. Sci. Rept. Agric. Res., 1952-53, 79-89 (1954).

Verma, A. K., D. Basu, P. S. Nath, S. Das, S. S. Ghatak and S. Mukhopaghyay : Relationship between the population of whitefly, Bemisia tabaci Genn. (Homoptera: Aleyrodidae) and the incidence of tomato leaf curl virus disease. Ind. J. Mycol. Res., 27, 49-52 (1989).

Zeshan, M. A., M. A. Khan., S. Ali and M. Arshad: Correlation of conducive environmental conditions for the development of whitefly, Bemisia tabaci population in different tomato genotypes. Pak. J. Zool., 47, 1511-1515, (2015). 